What Drives the Tax Avoidance Strategies Adopted by US MNEs? Understanding the Heterogeneity of Approaches to Corporate Tax Planning in US Multinational Enterprises

\title{
Maggie Cooper
}

Ph.D. awarded by University of Reading (December 2017)

\section{Big Question:}

"What drives tax avoidance strategies adopted by US MNEs and why do they differ in their approaches?"

\section{Introduction}

My thesis considers the question: "What drives the tax avoidance strategies adopted by US MNEs?" The innovative research aims to provide a greater understanding of the different approaches to corporate tax planning used by US multinational enterprises (MNEs) and their subsidiaries in the UK. I used a mixed methods approach, driven by the need to generate new data in an area where confidentiality is key. My research included a series of interviews with senior tax executives, statistical analysis of a new hand-collected database of 94 companies and a series of case studies based on secondary data.

In recent years corporate tax avoidance has come under scrutiny from the public, the media, and the government; this thesis argues that it is vital that academic research is able to contribute to and lead this debate. There is a growing awareness of the ability of multinationals to shift profits between countries, that they can choose where to book profits and therefore where they pay tax. This ability to shift profits is increasing, with competition between countries intensifying as they reduce statutory tax rates in order to attract FDI.
Whilst tax may not drive the fundamental strategic direction of an MNE, it is likely to be considered as a key factor in the implementation of strategic plans. Cases such as the failed $\$ 160$ billion Pfizer-Allergan merger (Financial Times, 2016) and the European Commission's conclusion that the agreements between Ireland and Apple constituted a breach of the EU state aid rules (Economist, 2016) and the demand that they pay $€ 13$ billion in additional tax and interest, demonstrate the scale of potential tax savings. Policymakers need information about the factors that drive the level of aggression with which MNEs pursue a tax avoidance strategy. It is generally understood that the current tax system fails to deal well with modern companies, and digital companies in particular. Many of the companies that are cited as tax avoiding companies operate in the digital sphere (including Facebook, Google, and Amazon) but others such as Starbucks operate with a more traditional "bricks and mortar" business model. Consequently, my research endeavours to provide a greater understanding of what drives the differences between companies. I also argue that this is an important area of study for those working in the field of IB which has been neglected in recent years, although I welcome the more recent publication of articles in this area.

The literature review for this thesis draws on work conducted in the fields of accounting, public economics, and finance. The cross-cutting approach gives a comprehensive overview of the issues and again clearly highlights the need for new work to be carried out from within the field of international business (IB). 
My empirical findings are broad, with implications for researchers, practitioners, and policymakers. I demonstrate that MNEs, or those working within them, make choices about how much tax should be paid and which locations they should pay it in. The scope for decision making in this field is not reflected in previous studies. Tax regulations provide a framework for MNEs to operate within but there is still much scope for decision making and interpretation within these rules. The findings from the interviews show the importance of the people and culture inside the business in terms of setting the tone for tax planning and strategy and the risk that the organisation is prepared to take.

My statistical analysis generates substantial new information about the characteristics of companies and what drives tax avoidance. The ownership of intellectual property and the use of tax havens give firms the ability to reduce the taxes paid. Similarly, the larger the company, the less tax is paid. The more women there are on the board of a company, the more tax is paid.

My research makes another new finding: MNEs adopt strategies to optimise rather than minimise their corporation tax expense. This can make measuring tax avoidance and evaluating the scale of the problem difficult. There are important findings in my comparison of different measures of tax paid for researchers who want to understand the ways in which these measures differ.

\section{Research Methods}

The adoption of the specific research methods used for this thesis was driven by the need to find data that would contribute to a comprehensive understanding of what is happening inside the "black box" of the company. A holistic and systematic mixed methods approach was used, including both qualitative and quantitative methodologies. The combination of different approaches helps to overcome the issues of confidentiality, which are clearly significant when researching in this area.

The first empirical study is based on a series of eleven interviews with senior tax executives from UK subsidiaries of US MNEs and experts of tax advisory firms, focusing on the experience of the MNE subsidiaries operating in the UK. The interviews were analysed using Nvivo specialist software, enabling specific themes to be identified and used to code the interview transcripts.
The second empirical study concerns the statistical analysis of a hand collected database of 94 largest US MNEs operating in the UK. The size of the database was carefully considered to ensure that the findings could be effectively analysed using statistical techniques but this was balanced against the necessity to generate data that could be interpreted with reference to the individual companies. This, therefore, enables the data analysis to contribute to establishing a holistic view of the focal companies. Significant new findings are generated using multiple regression techniques. The statistical analysis is complemented with outlier analysis and the case studies discussed below.

In the third empirical study, an indepth analysis of a series of six case studies (Amazon, Ford Motor Company, Goodyear Tires, Google, Starbucks, and Nucor) are presented. The case studies are developed using content analysis methodology based on published accounting data and other company information (e.g., management discussion, disclosure notes, and organizational structure and business configuration) and public information sources. The case studies make a clear contribution by providing a rich, detailed analysis of the companies involved over a ten-year time horizon. The case studies aim to complement the findings from the previous two empirical studies - the interviews and the parent-level data analysis.

\section{Theoretical Contribution}

Internalization theory underpins the research contained in this thesis. Tax was explicitly at the centre of research interest in early IB theory (Rugman, 1980; Rugman \& Eden, 1985), which discussed the benefits that transfer pricing and tax confer on the MNE; tax planning, it was argued, gives MNEs a financial advantage over domestic companies. Internal financial transfers enabled MNEs to overcome the liability of foreignness and external capital market imperfections (Hymer, 1976). Over time, however, these transfers within the MNE came to be seen as less central to the overall theory of the MNE. Transfer pricing, referring to the prices used for the flow of intermediate or finished goods or services between affiliates of the same firm, is now viewed simply as a mechanism employed by MNEs to avoid taxes rather than as a core, innate part of the advantage of the MNE (Casson 1979). 
Figure 1. Motivation-Opportunity Matrix

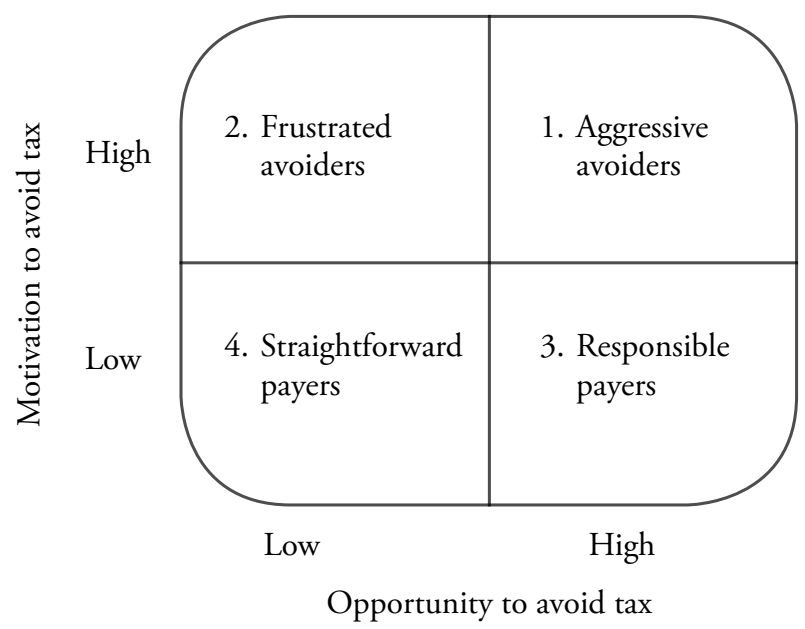

Tax avoidance was explicitly included in Dunning's (1993) work on motivation - not in the "big four" that are so commonly quoted, but as part of the "escape" motive. He directly addressed tax avoidance as a motive for FDI here. My work considers the different factors that could affect a MNE's motivation to avoid tax, in combination with the opportunities that are available to them. I categorise companies using a $2 \times 2$ matrix (see Fig. 1).

This is one of the key theoretical contributions made in my thesis. Further work is now needed to test this framework.

\section{Empiricall Work}

The three separate research studies each make significant new empirical contributions to the literature. Specifically, findings from the innovative interview research, supplemented with the parent companies and the UK subsidiaries' annual reports, prospectus, and documents, suggest the importance of aspects such as the experience of individuals and the company's overall attitude to risk, that the development of theory must take into account. The research clearly demonstrates that the background and experiences of those involved in setting and managing tax policy within the MNE will have an impact on its overall strategy. The overall aggressiveness of behaviour that emerges will be a consequence of motivations and opportunities available to MNEs.

As discussed above, the regression analysis investigates the importance of different characteristics of the firm and the impact that these have on their tax avoidance strategy. This study offers an in-depth analysis of a small dataset. An economic model is established and hypotheses are drawn from this model. These are then tested, revealing the importance of intellectual property and tax havens as means of reducing the effective tax rate (ETR) paid. The number of tax haven subsidiaries does not appear to impact the level of tax paid as companies had between
179 and zero tax haven subsidiaries. The advantage is conferred simply by having a single tax haven subsidiary.

The size of a firm and the proportion of women on the board are important factors in determining the level of aggression with which a MNE addresses its corporate tax planning. In other words, the largest companies and those with fewer women on the board pay less tax. My analysis also confirms that MNEs adopt strategies that enable them intentionally to avoid taxes and that some firms pursue these more aggressively than others. Again, the scope for decision makers to have an impact on tax strategy is clear.

The case study research presents important new detailed information about the role of tax planning within the MNEs studied. The case studies demonstrate the broad range of approaches adopted by MNEs and the impact that this has on their corporate strategy as well as on the financial reporting. These case studies also demonstrate the potential for robust data generated through the in-depth analysis of annual reports to contribute to future IB research.

It is argued that one reason for the neglect of this area is the difficulty encountered in gaining access to information due its highly confidential nature. The innovative triangulation of qualitative and quantitative research methods used demonstrates that whilst data is hard to access, it is not impossible. The case studies, in particular, highlight the depth of information that is available to researchers within annual reports, a source which is often overlooked by IB researchers who may lack the technical skills to access it.

\section{Implications for International Busi= ness Theory and Practice}

In this thesis I argue that tax has risen up the political agenda, particularly since the financial crisis of 2008. Governments, the OECD, and the EU have all generated work programmes to understand profit shifting and tax avoidance. My three pieces of research demonstrate the flexibility that MNEs currently experience within the international tax regime given that the differentials in tax rates across countries provide MNEs with vast opportunities for arbitrage. MNEs demonstrate behaviours that enable them to plan their tax liabilities.

This research will add to policymakers' understanding of MNE corporate tax planning and strategy. Understanding the way in which decisions made within the "black box" of the MNE is imperative to generating effective government policy. Understanding the means by which MNEs exploit lower tax rates to reduce their overall corporation tax bill is essential for public policymakers wishing to change MNE behaviour. 
My thesis demonstrates that MNEs do not adopt a homogenous approach to tax planning, and government policies need to respond to these differences. MNEs operate across borders and the case studies presented demonstrate the extent of the impact of tax planning on their corporate structures and behaviour. Without a similar transnational perspective, governments will be at a disadvantage compared to the MNE, focusing on a smaller jurisdiction than does the MNE. As the length of value chains increases, all MNEs, not simply those involved in digital industries, will be able to exploit tax planning possibilities.

There are clear implications for the managers of MNEs - both at the headquarters and at the subsidiary level. Management needs to be clear that when they are setting their tax planning strategy they are making a choice with implications not only for the corporation tax paid but also, potentially, risks to the business including those of public perception and potential damage to their corporate reputation. Executives should actively manage their tax planning strategy in the light of these potential trade-offs.

\section{Conclusion}

This is an important area for MNEs. Tax is often the single largest bill that they pay during the year. It directly affects their behaviour and the implementation of strategy. It is vital that IB research is conducted in this area to ensure the relevance of the field to policymakers as well as managers. The research in this thesis takes an innovative approach to generating new information. The data generated then highlights significant differences in approaches taken between companies and the importance of decision making by corporate management.

\section{References}

Casson, M. 1979. Alternatives to the Multinational Enterprise. London: Macmillan.

Dunning, J. 1993. Multinational Enterprises and the Global Economy. Harlow: Addison-Wesley.

The Economist. 2016. The 13 billion bite. 3/9/2016. Available at: http://www.economist.com/news/business/21706238-europeancommissions-huge-penalty-against-apple-opens-up-new-front-wartax [Accessed: 3/9/2016]

Financial Times. 2016. Pfizer to kill \$160bn Allergan merger. 6/4/2016. Available at: https://www.ft.com/content/edb7f406-efbe-37f3-84f2-78ab75f0cb10 Accessed 6/4/2016]

Hymer, S. 1976. The International Operations of National Firms: A Study of Direct Foreign Investment. Cambridge, MA: MIT Press.

Rugman, A. 1980. Internalization Theory and Corporate International Finance. California Management Review, 23(2): 73-79.

Rugman, A., \& Eden, L. (Eds) 1985. Multinationals and Transfer Pricing. London: Croom Helm.
Maggie Cooper (Maggie.Cooper@henley.ac.uk) is a Lecturer at Henley Business School, University of Reading where she received her Ph.D. Maggie also holds Masters degrees in International Business from the University of Reading and in Management in the Public Sector from the University of London. Her research interests include tax avoidance within corporate strategy and decision making in the MNE. Her current research includes the ethical implications of tax for executives and its role within the CSR agenda. 